\title{
Disturbances and biodiversity in forest ecosystems: A temperate zone perspective
}

\author{
Anton Fischer \\ Geobotany, Center of Life and Food Sciences, Technische Universität München TUM, \\ Hans-Carl-von-Carlowitz-Platz 2, D - 85354 Freising, Germany
}

\begin{abstract}
In the temperate zone windstorms and bark beetle attacks represent the main natural forest disturbances; in steep mountain areas snow avalanches also may "destroy" forest stands completely. In the densely populated and intensively used temperate zone of Europe affected forest stands will be cleared and reforested immediately after such "catastrophes". Therefore we have only little knowledge about the influence of such natural disturbances on both the stand development and the biodiversity of native forest ecosystems. And we do not have quantitative data on to which degree forest management changes the biodiversity compared to the natural disturbances. Since about two decades several permanent plot studies have been running in European forests affected by such natural disturbances, mainly with focus on plant species. Here we first outline the importance of disturbances for biodiversity in forest ecosystems and then discuss whether it is possible to combine both biodiversity protection and forest management. For that we use four recent case studies carried out in the two oldest national parks in Germany, three of them being long-term observations on permanent plots for up to two decades. Disturbances like wind throw, bark beetle outbreak and snow avalanche strongly influences the tree layer structure, creating micro-habitats for many plant, animal and fungi species, which naturally belong to the forest ecosystem. Such disturbances in future should be included into management schemes in forestry to improve biodiversity. We found evidence that it is really possible to combine timber utilization with biodiversity protection. As long as the management impact is reduced (e.g. single tree harvesting, using natural regeneration), species diversity of several taxonomic groups (in our study: vascular plants, soil living Carabidae, and soil living fungi) may not be different significantly from a pristine forest. Interconnecting resource use with biodiversity protection will be a main task for both foresters and conservationist in the decades to come - and it seems to be a possible option for a sustainable land use in many parts of the world.
\end{abstract}

Key-words: avalanche, bark beetle outbreak, forest management, protection, succession, wind throw.

\section{Introduction}

Biodiversity (Wilson 1988 a) generally means the number of biological units per unit area, including the gene, species, community/ecosystem, and landscape, summarised as the variety of life. As the recent Global Biodiversity Outlook 3 (Secretariat of the CBD 2010) drastically shows, the global

Correspondence,

e-mail: a.fischer@wzw.tum.de; Tel: +498161714730. biodiversity is strongly decreasing and the UN target "to achieve a significant reduction in the rate of biodiversity loss by 2010 ... has not been met” (p. 5). The variety of life conflicts with the variety of utilization demands of mankind. Most important for global biodiversity decrease is the human population increase. According to the UN "State of the World Population 2010" report, recently population increases by 2.6 humans per second, resulting in a global human population of 7.96 to 10.46 billion in 2050. At the same time the demands 
per head are increasing: e.g. world annual meat consumption per head increased from $18 \mathrm{~kg}$ in 1950 to $36 \mathrm{~kg}$ in 1999 (www.fao.org). To meet all these demands more agricultural land is needed, more water (potable water, irrigation water) used, more timber cut, more roads and settlements constructed, leading to increasing landscape degradation and fragmentation, decrease of natural habitats/ecosystems, while at the same time more waste is produced, more pollution emitted (e.g. $\mathrm{CO}_{2}$, leading to global climate change). As Sala et al. (2000) already mentioned land use is the major driver of changes in biodiversity. "Land use" concerning forests mainly in tropical and subtropical Africa and South America means cutting timber and conversion of forest land into different kinds of arable land (currently around 4 million hectares per year in each continent, FAO 2006: www.org/forests/site/fra/en), while in Europe and SE Asia (mainly China) forest area is increasing since 1990, mainly because of reforestation (but tree plantations are emerging, not the former forest ecosystems reconstructed). The tropical (and subtropical) forests at the same time are the main carriers of species diversity (Wilson 1988 b, Seligmann et al. 2007).

Why here "a temperate zone perspective" is given, although not any place of the temperate zone of the northern hemisphere belongs to the centers of biodiversity? In the European temperate zone, the phase of forest destruction took place already a couple of centuries ago. Germany is a well documented example: although under current climate conditions nearly the whole country area is potential forest land (with the exception of few high mountains and few bogs), up to the $14^{\text {th }}$ century the forested area had been reduced to less than 20\% (Bork 1998). The looming timber deficiency was the major reason to develop the idea of "sustainable" use of renewable resources. The term "sustainable" had first been used in the textbook of Hans Carl von Carlowitz "Sylvicultura Oeconomica”, published in 1713 in the former Kingdom of Saxony, now belonging to Germany. Since then the concept of "near-natural forestry" had been developed in Germany, and a lot of research in sustainable forest management as well as in forest ecology had been carried out; consequently, the forest area has increased (to around $30 \%$ today).

The goals of this paper are (1) to outline the importance of disturbances for biodiversity in forest ecosystems, and (2) to show that it is possible to combine both biodiversity protection and forest utilization. For this purpose, I will outline four case studies, carried out in two German national parks, dealing with the influence of wind throw, bark beetle outbreak, snow avalanche, and management on structure and species composition of forest stands.

\section{Materials and Methods}

The four case studies were carried out in the two oldest German national parks, both in the SE of Germany (Figure 1): Bavarian Forest National Park and Berchtesgaden National Park. Bavarian Forest National Park, founded in 1970, covers the central part of a mountain range called "Bavarian Forest" along the border to Czech Republic. It is nearly totally covered by forests, including three main forest types: (1) the Norway spruce (Picea abies (L.) Karstens) forest in the wet and cold flat valley bottoms (700-800 m asl), (2) the mountain mixed forest with European beech (Fagus sylvatica L.), white fir (Abies alba Mill.) and Norway spruce (Picea abies) up to $1150 \mathrm{~m}$ asl, and (3) the high mountain spruce forest (Picea abies) up to the highest top of the national park (mount Rachel, $1453 \mathrm{~m}$ asl). Case studies presented here cover all the three forest types.

Berchtesgaden National Park is situated in the Northern Calcareous Alps, surrounded at three sides by Austria. Being a protected area since the beginning of the $20^{\text {th }}$ century, the national park was founded in 1978. It reaches from Lake Königssee (603 m asl) up to the top of Mount Watzmann ( $2713 \mathrm{~m}$ asl). The area below the timber line is mostly covered

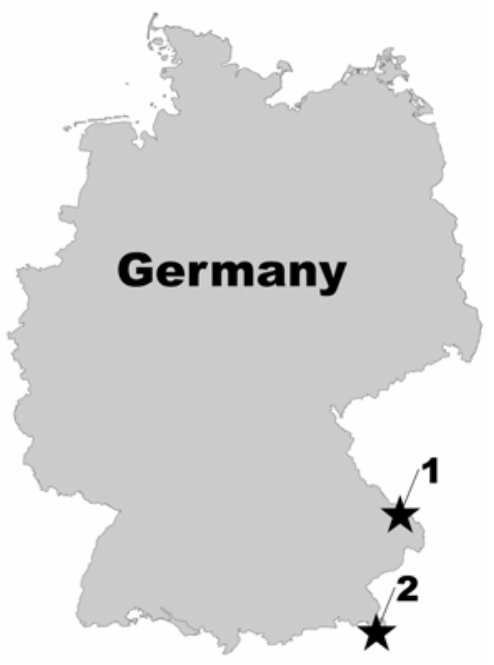

Figure 1. The Bavarian Forest National Park (1) and the Berchtesgaden National Park (2) in the SE of Germany (Map: (C) Bundesamt für Kartographie und Geodäsie, Frankfurt/M. 2011). 
by forests. The case study was carried out in the mountain mixed forest zone.

The case studies either deal with the species composition of all vascular plants (Case Studies 1 and 3), only with the trees (Case Study 2) or with vascular plants, soil dwelling Carabidae beetles and soil dwelling fungi (Case Study 4). They use sets of permanently marked sample plots of $10 \times 10 \mathrm{~m}$ (76 in Case Study 1, 46 in Case Study 3), 24 randomly chosen sample plots (permanently marked) of 40 x $40 \mathrm{~m}$ with 76 subplots of $0.5 \mathrm{~m}^{2}$ each (Case Study 2), and 4 sets (3 replicates each) of forest patches of up to 0.5 ha (Case Study 4). They were carried out in 1988, 1993, 1998, 2003 and 2008 (Case Study 1), in 1998-2000 and 2004 (Case Study 2), in 1989, 1994, 1999 and 2010 (Case Study 3) and 1999-2001 (Case Study 4). For more details see the cited publications.

\section{Results}

WIND THROW (CASE STUDY 1)

Although Central Europe is the core center of the distribution of European beech (Fagus sylvatica L.) worldwide and without impact of man F. sylvatica would be the dominating tree species, today most dominating in managed forests is Norway spruce (Picea abies). In such managed forests each disturbed forest patch will be cleared and replanted, so the knowledge on patch dynamics of Central European natural forests for a long time was limited. Managed stands are poor in vascular species and they are endangered by storm-felling as well as by bark beetle outbreaks, both expected to increase with the expected increasing temperature in future. It was a unique chance to study succession following wind throw in unmanaged forests, when on $1^{\text {st }}$ August 1983 a local storm blew down natural spruce forests in the Bavarian Forest National Park: the national park administration at that time decided to leave some wind thrown forest stands unmanaged, while others were cleared, but not replanted. It was the first time in Central Europe to analyze the succession following such a storm event with and without management impact. We set up permanent plots for vegetation analysis in 1988 (Fischer et al. 1990) and repeated records every five years until 2008.

After clearing a felled-area, vegetation developed (with Rubus idaeus L. and Epilobium angustifolium L. as indicator species), replaced after several years by birch (Betula) pioneer forest. Many of the pre-existing spruce seedlings and saplings were destroyed during the clearing procedure, so that spruce regeneration was delayed. This is the always occurring succession sequence in managed forests.

On the unmanaged sites, however, the former ground layer forest species continued to grow, felled-area species were restricted to disturbed sites (pit-and-mound-system of uprooted trees), and the existing spruce saplings immediately after the event started to build up a new tree layer (Fischer and Fischer 2009).

Figure 2 represents the successional differences, comparing managed (= cleared) and unmanaged wind throw areas as well as surrounding not affected forests. The affected forest are still clearly separated from he reference forests, but unmanaged stands from the beginning are closer to the forest reference than cleared. The structural diversity was high on unmanaged areas (decaying dead wood, dead and dying standing trees, trees of different age and size, pit-and-moundsystems) but low on managed (no dead wood, area structurally homogenized by clearing procedure, birch population of same age and same size dominating the regenerating tree layer). An

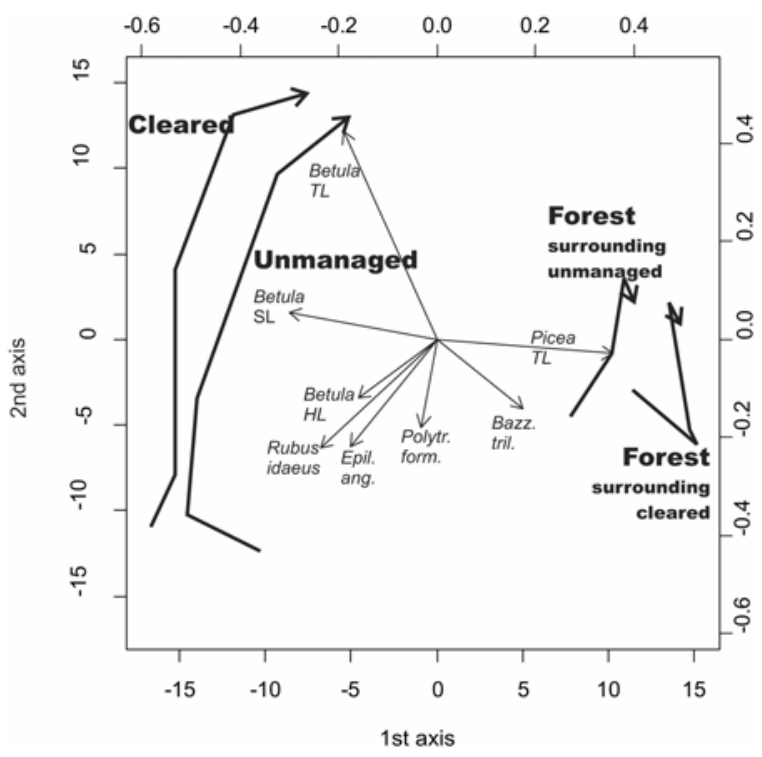

Figure 2. PCA of all wind throw plots as well as plots of the surrounding forests. Bold arrows mark the successive states (1988, 1993, 1998, 2003 and 2008). Explaining plant species are: Betula/Picea $(\mathrm{TL}=$ tree layer, $\mathrm{SL}=$ shrub layer, $\mathrm{HL}=$ herb layer), Epilobium angustifolium, Polytricum formosum, Bazzania trilobata. Left and bottom scale: sample scores; right and top scale: species scores. Drawn from Fischer and Fischer (2009). 
individual based modelling approach showed that within the next century spruce will dominate on both areas, but on managed areas birch will remain a significant part of the tree layer, pointing on the human impact (clearing procedure), while without management impact birch will be reduced to low values soon (Fischer et al. 2002).

In summary, it becomes obvious that without clearing, the species combination remains closer to the forest situation ("more natural"), and that the unmanaged stands are structurally richer than the managed ones.

\section{BARK BEETLE OUTBREAK (CASE STUDY 2)}

In the second half of the 1990s, a large scale die-back of the Norway spruce (Picea abies) trees of the natural high mountain spruce forests in the Bavarian Forest National Park occurred because of a bark beetle (Ips typographus) outbreak, meanwhile covering more than 2000 ha of the subalpine belt in this national park (Heurich 2009), and more in the adjacent Šumava National Park on the Czech site. At the beginning of the outbreak, many people, including several foresters, considered this was an ecological disaster, because the forest seemed to disappear. Therefore, in 1998, we implemented a research program to analyze tree regeneration potential in the subalpine zone of the national park. We labeled and counted all the tree individuals (age, survival rate of cohorts, height, annual height increase, vitality; including all seedlings since germination) on the test plots in the first year (1998) and repeated the records in 1999 and 2000 (Bauer et al. 2008).

At that time (end of the 1990s), among the dead spruce trees indeed only very few young trees larger than $0.5 \mathrm{~m}$ could be seen in the area. Nevertheless, including all the very small and young seedling, in 1998 we found (mean value) around 29,000 tree individuals smaller than $0.5 \mathrm{~m}$ per hectare. This number decreased to less than 13,000 in the year 2000, representing a very young population (Figure 3). Based on this data we were able to calculate the number of trees larger than $10 \mathrm{~cm}$ (such spruce seedlings have a very high change to survive) for the years 2003-2005 (peak) by 6,800-6,900 per hectare. In 2004 we repeated the record on one third of the plots, finding 7,895 individuals per ha. Heurich (2009), using a completely different method, found 4,502 individuals larger than $20 \mathrm{~cm}$. According to Korpel (1995) from the Western Carpathians, and Kuuvuainen et al. (1998) from pristine forests in northeastern Europe, less than 3,000 saplings larger than $10 \mathrm{~cm}$ per hectare are enough to regenerate a tree layer in such forests.

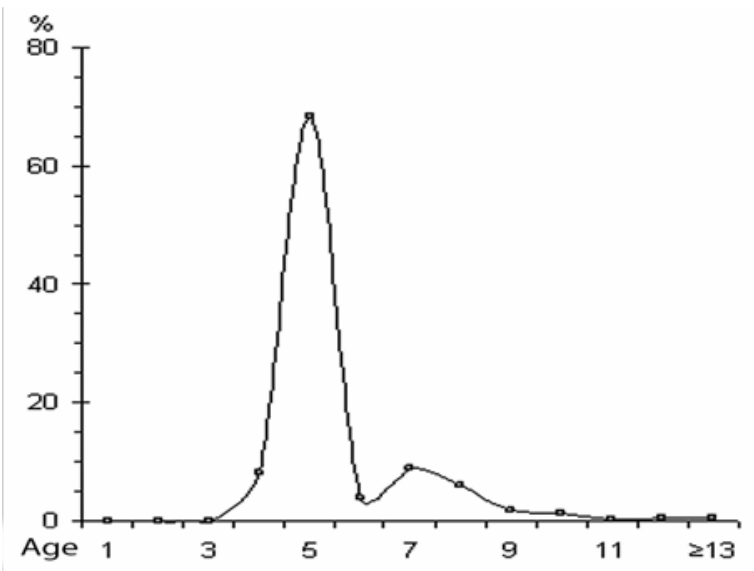

Figure 3. Distribution of age (years) of natural spruce regeneration in 2000. Drawn from Bauer et al. (2008).

In summary, there are more young trees regenerating a new tree layer than needed; not the "forest" is dying but (a high number of) trees. The density of tree regeneration, however, is variable within the area, resulting in a patchy population mosaic. The new forest will be richer in structures than the old one. Most important to learn that spruce forests regenerate on a large scale, but not, as many deciduous forests, by dying and replacement of single trees or small groups of trees.

\section{SNOW AVALANCHE (CASE STUDY 3)}

Snow avalanches usually affect subalpine forest ecosystems and play an important role for the forest structure there, but were rarely studied up to now (Bebi et al. 2009). A much more rare event is that a snow avalanche affects a mountain mixed forest. This happened on 18 January 1986 in the Berchtesgaden National Park in the Northern Calcareous Alps. The snow masses originated from the east-facing steep slopes of Mount Watzmann, the highest mountain in the Berchtesgaden National Park. The snow masses passed through the mountain mixed forest belt, in this area mainly composed of European beech (Fagus sylvatica) and sycamore maple (Acer pseudoplatanus L.). The avalanche stopped in $610 \mathrm{~m}$ asl, shortly before reaching the banks of Lake Königssee (603 $\mathrm{m}$ asl). Because this area has not been used since nearly one century, there are only few data available about former structure of the forest. An aerial photograph dating from 1980 seems to show that between 1940 and 1950 an earlier avalanche event took place. The trees hidden in 1986, therefore, 


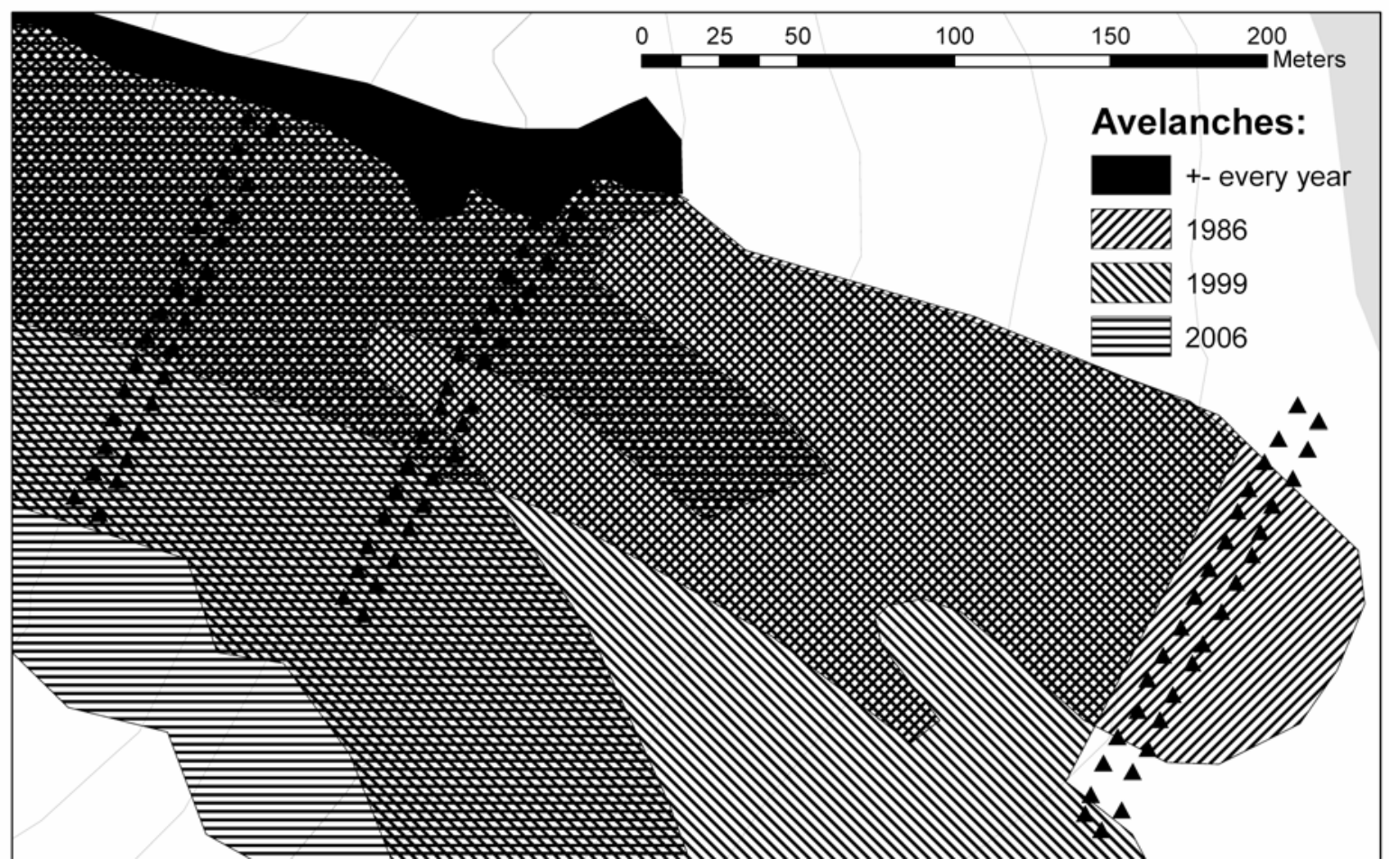

Figure 4. Mosaic of different structural types depending on time of disturbance (age after disturbance), frequency of disturbance, and type of disturbance (former upright growing trees either bent to the ground or broken/uprooted). Drawn from Fischer et al. 2011. Right above: banks of Lake Königssee, $603 \mathrm{~m}$ asl.

were relatively young (around 40-50 years). That caused another very unusual situation: the trees were not broken or uprooted, but very bent over, and they survived in their new position. Branches now staying on the upper site of the (former) main trunk grow up forming new stems. As a consequence for the forest plants living on the ground this strong event did not change the site conditions fundamentally: the forest canopy remained living, pressed by the snow to the ground, reducing sunlight instead of increasing it. Seen from outside it appeared to be a tree layer destroying event, but seen from the point of view of the forest ground layer vegetation there was no significant change of micro-habitat.

To investigate the regeneration of the forest in the long run we established a set of permanent plots (3 transects), also including the surrounding forests of the avalanche track as reference (Fischer 1997).

Unexpected again a new avalanche came down in January 1999, following the 1986 track. On the former track it stopped directly in front of the lowest transect, but it destroyed the old forest SE of the former track (including most of the reference plots). There, in contrast to the 1986 avalanche, it really uprooted, broke, and therefore killed the (around 200 years old) trees, forming something like a "natural clear cut”. In February 2009, a new avalanche destroyed the old forest stands further SE (but in this area we have no permanent plots).

While the intention of the permanent plot study originally was only to analyze the succession, after the disturbance, in the long run, we now have the opportunity to see the forest vegetation differentiation depending on a series of different intense events (Fischer et al. 2009).

On the whole study site (around $11 \mathrm{ha}$ ), the series of avalanches resulted in a mosaic of seven separated areas that differ in (i) time of disturbance, (ii) frequency of disturbance and (iii) type of disturbance (Figure 4). Comparing the species composition of 46 plots (3 transects) and 4 recording times (1989, 1994, 1999, 2010), using Jaccard-Index of similarity, we were able to differentiate 13 different 'species 
assemblages', resulting in 8 different 'succession pathways' represented on the test area (Fischer et al. 20011).

In summary, the series of snow avalanches, starting with a rather homogeneous forest cover, created a mosaic of different forest structures (standing trees versus trees bent to the ground versus uprooted trees; young versus old trees) and succession pathways, giving habitat not only for different plant species (developing different plant communities) but (expected) also for a lot of different animal and fungi species/communities, both in time and space.

\section{FOREST UTILISATION VERSUS FOREST PROTECTION (CASE STUDY 4)}

It is a question of general importance whether forest biodiversity protection means exclusion of forest utilization, or whether both can be realized on the same site. To investigate this topic in the mountain mixed forest belt of the Bavarian Forest National Park, we analyzed biodiversity in four different disturbance situations (all other conditions as similar as possible): (i) any disturbance: natural forest, not managed since decades, (ii) forest managed in a near-natural way: single tree cut, natural regeneration used, (iii) natural disturbance: some trees (spruces) killed by bark beetles, but the still standing trees not extracted, and (iv) strong man-made disturbance: clear-cutting the whole stand after bark beetle infestation.

The following taxonomic groups were analyzed: vascular plants (Mayer 2002), Carabidae beetles living in and on the soil (Liepold 2004), soil fungi (not including dead wood species) (Hahn 2007).

In Figure 5, the species composition of vascular plants plus the soil living Carabidae plus the soil fungi of the four different disturbance situations (three replicates each) in mountain forest ecosystem are compared. On the left site of DCA axis 1 , the plots of "undisturbed natural forest" and "near-naturally managed forest" are mixed. On the right side, the cleared plots are situated. The "natural forest with standing dead spruce” is between both. The main explaining variables are light (right side of DCA axis in Figure 5) and living spruce (left side of DCA axis). Lot of light is characteristic for cleared areas and presence of living spruces for forests. The results are supported by negative relationship of living beech (represented by arrow 2 in Figure 5) and total number of living trees (arrow 3 ) with the scores of DCA axis 1, and positive relationship of number of stumps (arrow 6) as well as forest tracks (arrow 8) with the the scores of DCA axis 1. Thus, axis 1 can be interpreted as a disturbance gradient.

In summary, the study demonstrates that forests for a long time unaffected by man (as close to the natural situation as possible in a developed country) may not significantly be different from forests that are used in an adaptive way (extraction of single trees only, use of natural regeneration). In other words, the single tree management system in this type of forest comes close to unmanaged or "natural" in respect to species diversity.

\section{Discussion}

Forests are important hosts for biodiversity. A lot of plant, animal and fungi species are living there, forming a lot of different communities and ecosystems, and having a wide range of genetic variation within each species. The Case Studies 1 to 3 show that disturbances in forest ecosystems enhance structural diversity: (i) an uncleared wind throw area with patches covered by fallen dead wood as well as open places without dead wood, pit-and-mound-systems around root-plates of uprooted trees, surviving old trees, surviving tree regeneration, (ii) areas affected by snow avalanche with broken or bent trees of different age, and (iii) standing and lying dead wood of different age with increased light conditions after bark beetle outbreak. This structural diversity results in to a high species (plants, animals, fungi) number per unit area (i.e., species diversity) and a high diversity of (micro-)habitats (i.e., community or habitat diversity), keeping biodiversity on a high natural level. A patchy mosaic is typical for a lot of temperate (mixed) deciduous forest ecosystems, as demonstrated by Zukrigl et al. (1963), Mayer et al. (1980), Abs et al. (1999), Brändli and Dowhanytsch (2003) from few remaining more or less pristine deciduous forests in remote parts of Europe.

Our Case Study 2 shows that regeneration in spruce forests may work on a larger level than that of deciduous forests: bark beetle may kill trees on hundreds of hectares simultaneously. Although this event really works on a landscape level, there is enough regeneration available to create a new forest canopy. The decaying wood, standing and lying, for several years to decades is giving habitat to a lot of bird (Moning and Müller 2008), insect (Müller et al. 2008, 2010) and fungi (Bässler and Müller 2010) species, which were rare 


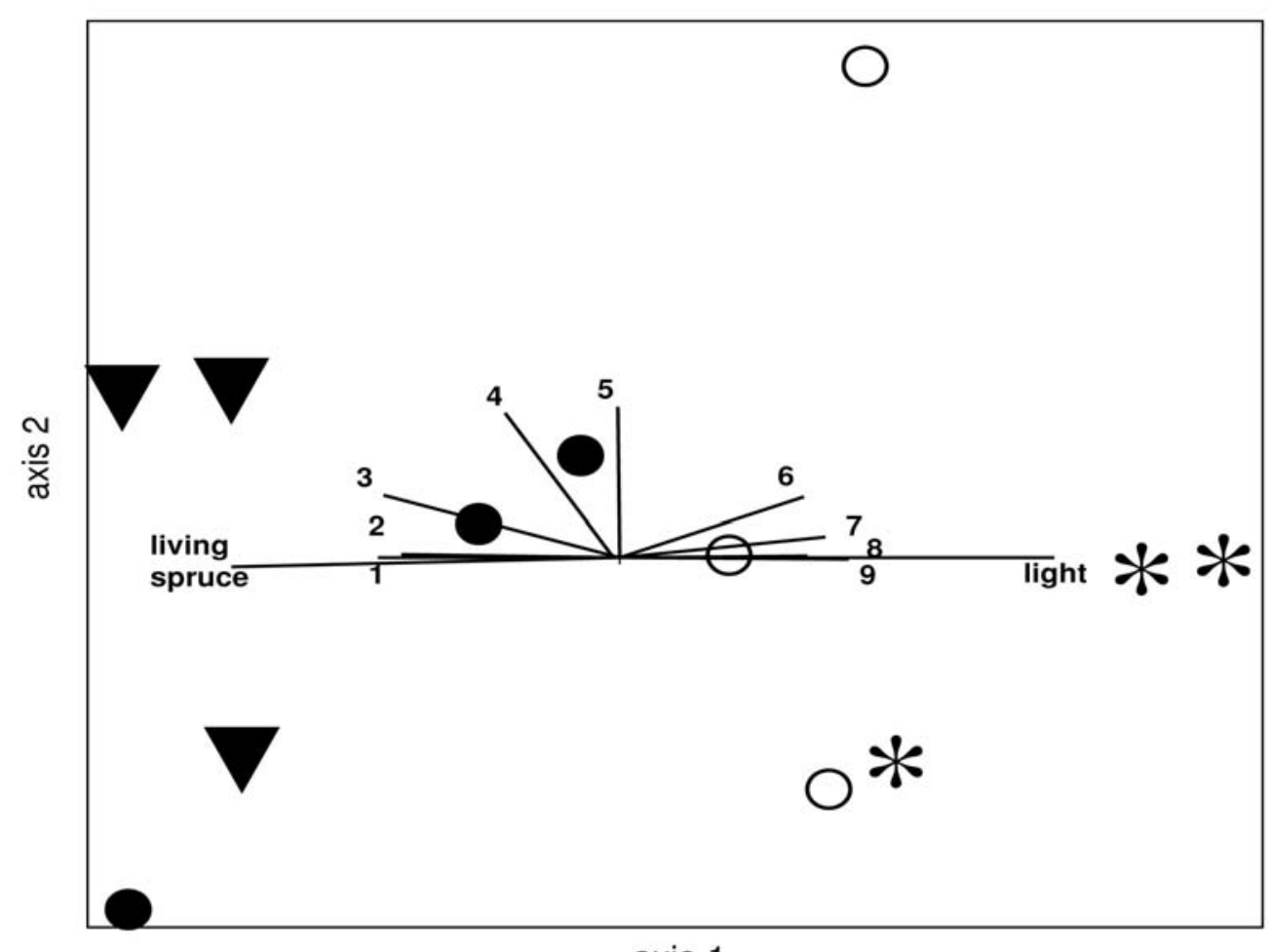

axis 1

Figure 5. Investigated plots according to their species similarity (DCA; presence/absence of vascular plants, soil Carabidae beetles, soil fungi). Four variants with three replicates each: Ï\% = unmanaged, 1/4\% managed: single stem harvesting, Ë\% unmanaged, spruce trees died because of bark beetle attack, * whole stand cleared because of bark beetle attack. Vectors of the most important (corr.coef. $>0.3$ ) habitat factors are shown: light $=$ mean radiation intensity, living spruce $=$ number of living spruces per ha, $1=$ basal area, 2 = number of living beech trees per ha, $3=$ total number of living trees per ha, $4=$ number of spruce per ha, $5=$ mean cation exchange capacity, $6=$ number of stumps per ha, $7=\mathrm{C} / \mathrm{N}$ ratio, $8=$ forest tracks, $9=$ cover degree of ground vegetation.

to extremely rare in the past decades (without large scale bark beetle infestation).

It becomes obvious that all these levels of biodiversity need a certain protection, and especially that disturbance in forests has to be accepted as a main driver of natural biodiversity. In protected areas, natural disturbances like wind throw or snow avalanche event or the sudden increase of the population of tree-killing insects or fungi should not be seen as a catastrophe but more as a change for re-establishing the former existing level of biodiversity.

On the other hand, timber is a very useful forest product. It is the most important renewable resource worldwide. While using it for building houses and bridges and using it as energy carrier, the timber substitutes e.g. concrete and steal, mineral oil and coal. Therefore, timber utilization is important especially in times of global climate change, mainly driven by increasing amounts of $\mathrm{CO}_{2}$ in the atmosphere. Timber utilization, however, means forest utilization. Does the one exclude the other, or is a combination possible?

Firstly, in managed forests, not each disturbed small area has to be cleared and replanted immediately. In some cases, time- and cost-intensive clearing procedures, after such events, and planting of new trees may not be needed also from an economically point of view. In remote, steep or wet areas it may be better to wait for natural regeneration than to harvest the timber and re-plant the area as soon as possible. Leaving some of such patches untouched is a contribution to improve the level of natural structural, species, and community diversity.

Secondly, as Case Study 4 clearly demonstrated, it is possible to use the forest as a timber resource without fundamentally changing the species diversity of important 
functional species groups. Insect and fungi species, depending on coarse woody debris, were excluded in this study because the overwhelming importance of dead wood for high numbers of such species is well-known (Harmon et al. 1986; Samuelsson et al. 1994). Therefore, leaving some standing and lying dead wood in the forests also improves the biodiversity. Similar results (concerning vascular plants) had been found in a pristine temperate lowland deciduous forest in eastern Poland (Abs et al. 1999): although the forest structure had been significantly changed by management, the vascular species composition in both managed and pristine forest stands was very similar (a bit higher in managed stands because of some additional disturbance indicators, more visible in the soil seed bank than in the actual vegetation).

A combination of protection and utilization therefore is possible, as long as the forest management is done in an adapted way. This conclusion may not be restricted to temperate forests only. In the tropical mountain rain forests of Ecuador, belonging to the centers of biodiversity (Seligmann et al. 2007), Wilcke et al. (2009) found that improvement felling (10\% of the initial basal area) did neither enhance nutrient leaching nor have impact on water fluxes, nutrient concentrations in all ecosystem solutions and therefore 'can be considered as sustainable with respect to water and nutrient cycles' (p. 1303). Günter et al. (2008) from the same study area showed that both ephiphytes and moths were not significantly influenced by the management changes. According to Günter et al. (2008), an ecologically sustainable management of neotropical mountain rain forests is possible if the disturbance is low and if the disturbance area is embedded within a matrix of undisturbed forests.

Using forest resources in a sustainable way - sustainable also regarding biodiversity - is much better compared with the complete conversion of a forest into agricultural land (as done in many parts of the tropics, see introduction).

"Interconnecting resource use with biodiversity protection", as already demanded in the FAO "State of the World Forests 2001" report, will be a main task for both foresters and conservationist in the decades to come - and it is possible.

\section{Acknowledgements}

The research projects presented here were mainly financed by the curatorship of the Bavarian State Institute of Forestry, Freising, Germany and the German Ministry for Science and
Education, Berlin. Additionally we have got a lot of practical and scientific support by the administrations of the two national parks. We thank our colleagues Prof. Dr. R. Schopf, TUM München, and Prof. Dr. R. Agerer, LMU München, for close cooperation in Case Study 4.

\section{References}

Abs C., Fischer A. and Falinski J.B. 1999. Vegetation ecology of primeval and managed forests. Comparison of TilioCarpinetum stands in the Bialowieza forest area (northeastern Poland). Forstwissenschaftliches Centralblatt 118: 181-196.

Bässler C. and Müller J. 2010. Importance of natural disturbance for recovery of the rare polyspore Antrodiella cirinella Niemelä and Ryvarden. Fungal Biology 114: 129-133.

Bauer M.L., Fischer A., El Kateb H. and Mosandl R. 2008. Verjüngungsdynamik nach großflächigem Borkenkäferbefall in den Fichtenwäldern der Hochlagen des Bayerischen Waldes. Allgemeine Forst- und Jagdzeitung 179: 43-52.

Bebi P., Kulakowski D. and Rixen Chr. 2009. Snow avalanche disturbances in forest ecosystems: State of research and implications for management. Forest Ecology and Management 257: 1883-1892.

Bork H.R. 1998. Landschaftsentwicklung in Mitteleuropa. KlettPerthes, Gotha, Germany.

Brändli U.B. and Dowhanytsch J. 2003. Urwälder im Zentrum Europas. Birmensdorf WSL.

Carlowitz H.C. von. 1713. Sylvicultura Oeconomica. Anweisung zur wilden Baumzucht. Leipzig. (reprint Freiberg 2000).

Fischer A. 1997. Vegetation dynamics in European beech forests. Annali di Botanica 55: 59-76.

Fischer A. and Fischer H. 2009. 25 Jahre Vegetationsentwicklung nach Sturmwurf - Eine Dauerbeobachtungsstudie im Bayerischen Wald. Forstarchiv 80: 163-172.

Fischer A., Abs G. and Lenz F. 1990. Natürliche Entwicklung von Waldbeständen nach Windwurf. Ansätze einer "Urwaldforschung" in der Bundesrepublik. Forstwissenschaftliches Centralblatt 109: 306-326.

Fischer A., Fischer H. and Lehnert U. 2009. Schneelawine als Störung im Bergmischwald. Laufener Spezialbeiträge 2/09: 19-25.

Fischer A., Fischer H. and Lehnert U. 2011. Avalanches creating high structural and floristic diversity in mountain mixed forests in the Alps. Biodiversity and Conservation. DOI 10.1007/ s10531-011-0204-z.

Fischer A., Lindner M., Abs C. and Lasch P. 2002. Vegetation dynamics in Central European forest ecosystems (near-natural as well as managed) after storm events. Folia Geobotanica 37: 17-32.

Günter S., Cabrera O., Weber M., Stimm B., Zimmermann M., Fiedler K., Knuth J., Wilcke W., Iost S., Makeschin F., Werner F., Gradstein R. and Mosandl R. 2008. Natural forest management in neotropical mountain rain forests: an ecological experiment. In: Gradients in a Tropical Mountain Ecosystem of Ecuador (E. Beck, ed). Ecological Studies 198: 363-375. 
Hahn C. 2007. Untersuchungen zur natürlichen Diversität der bodensaprotrophen und ektomykorrhizabildenden Großpilze des Dornfarn-Tannen-Buchenwalds in unterschiedlich genutzten und gestörten Beständen des Nationalparks Bayerischer Wald und seinem forstlich genutzten Umfeld. Diss TUM München. [online] URL: http://nbn-resolving.de/ urn/resolver.pl?urn:nbn:de:bvb:91-diss-20070419-620896-1-4.

Harmon M.E., Franklin J.F., Swanson F.J., Sollins P., Gregory S.V., Lattin J.D., Anderson N.H., Cline, S.P., Aumen N.G., Sedell J.R., Lienkaemper G.W., Cromack K. and Cummins K.W. 1986. Ecology of coarse woody debris in temperate ecosystems. Advances in Ecological Research 15: 133-276.

Heurich M. 2009. Progress of forest regeneration after large scale Ips typographus outbreak in the subalpine Pice abies forests of the Bavarian Forest National Park. Silva Gabreta 15: 49-66.

Korpel Št. 1995. Die Urwälder der Westkarpaten. G. Fischer, Stuttgart, Jena, New York, USA.

Kuuvulainen T., Syrjänene K. and Kalliola R. 1998. Structure of a pristine Picea abies forest in northeastern Europe. Journal of Vegetation Science 9: 563-574.

Liepold K. 2004. Vergleichende Untersuchungen zur faunistischen und genetischen Diversität von Käferzönosen in genutzten und ungenutzten Bergmischwäldern des Bayerischen Waldes. Diss TUM München. [online] URL: http://nbn-resolving.de/urn/resolver.pl?urn:nbn:de:bvb:91diss2004021311813.

Mayer H., Neumann M. and Sommer H.G. 1980. Bestandesaufbau und Verjüngungsdynamik unter dem Einfluss natürlicher Wilddichten im kroatischen Urwaldreservat Corkova Uvala/ Pliticer Seen. Schweiz. Z. Forstwesen 131: 45-70.

Mayer P. 2002. Processes of biodiversity change in forests: vascular plant species richness after disturbance in the Bavarian Forest. Diss. Technische Universität München, Germany.

Moning C. and Müller J. 2008. Environmental key factors and their thresholds for the avifauna of temperate mountain forests. Forest Ecology and Management 256: 1198-1208.

Müller J., Bussler H., Gossner N., Rettelbach T. and Duelli P. 2008. The European spruce bark beetle Ips typographus in a national park: from pest to keystone species. Biodiversity and Conservation 17: 2979-3001.

Müller J., Noss R.F., Bussler H. and Brandl R. 2010. Learning from a "benign neglect strategy" in a national park: Response of saproxylic beetles to dead wood accumulation. Biological Conservation 143: 2559-2569.

Sala O.E., Chapin F.S., Armesto J.J., Berlow E., Bloomfield J., Dirzo R., Huber-Sanwald E., Huenneke L.F., Jackson R.B., Kinzig A., Leemans R., Lodge D.M., Mooney H.A., Oesterheld M., Poff N.L., Sykes M.T., Walker B.H., Walker M. and Wall D. 2000. Global biodiversity scenarios for the year 2100 . Science 287: 1770-1774.

Samuelsson J., Gustafsson L. and Ingelög T. 1994. Dying and Dead Trees - a Review of their Importance for Biodiversity. Swedish Threatened Species Unit, Uppsala, Sweden.

Secretariat of the CBD (Convention on Biological Diversity). 2010. Global Biodiversity Oulook 3. Secretariat of the Convention on Biological Diversity (CBD) Monreal, Germany.

Seligmann P., Mittermeier A.R., Da Fonseca G.A.B., Gascon C., Crone N., Da Silva J.M.C., Famolare L., Bensted-Smith R., Rajaobelina L. and Beehler B. 2007. Centers for Biodiversity Conservation: Bringing Together Science, Partnership, and Human Well-being to Scale up Conservation Outcomes. Conservation International, Arlington, VA, USA.

Wilcke W., Günter S., Alt F., Geissler C., Boy J., Knuth J., Oelmann Y., Weber M., Valarezo C. and Mosandl R. 2009. Response of water and nutrient fluxes to improvement fellings in a tropical montane forest in Ecuador. Forest Ecology and Management 257: 1292-1304.

Wilson, E.O. (ed.) 1988 a. Biodiversity. National Academy Press, Washington D.C., USA.

Wilson E.O. 1988 b. The current state of biological diversity. In: Biodiverity (E.O. Wilson, ed.), pp. 3-18. National Academy Press, Washington D.C., USA.

Zukrigl K., Eckhart G. and Nather J. 1963. Standortskundliche und waldbauliche Untersuchungen in Urwaldreservaten der niederösterreichischen Kalkalpen. Mitt. Forstl. Bundesversuchsanstalt Mariabrunn 62: 1-244. 